\title{
Sharia Expression in Contemporary Indonesia: An Expansion from Politics to Economics
}

\author{
M. Zainal Anwar \\ IAIN Surakarta \\ Email: zainalanwar@gmail.com
}

\begin{abstract}
This study aims to describe the expression of sharia in contemporary Indonesia especially in the post reform era. In the beginning of reform, sharia appeared as the political actualization indicated with the demand for returning the seven words of the Jakarta Charter to the local government bylaws. Recently, sharia extends its coverage to economic fields, such as accommodation in industry w ith the emergence of sharia-labeled hotels, halal tourism and the like. This article departs from an argument stating that the extension of the meaning of sharia is inseparable from the interest of actors utilizing its label or brand to show political identity and businessinterests. This article describes this shift and analyzes the factors that affect this shifting from politics to economics. Drawing from the theoretical perspective of the contemporary sharia, stating that sharia contains a broad spectrum applied to many levels and aspects, this article argues that that sharia no longer has a single normative definition but has encountered meaning development corresponding to the social and historical challenges. This article also shows that sharia expansion into economic fields is now ongoing process in contemporary Indonesia.
\end{abstract}

Keywords: sharia, sharia expansion, political identity, economic identity

DOI: http://dx.doi.org/10.20414/ujis.v22i1.295

\section{Introduction}

THIS ARTICLE addresses sharia dynamics in Indonesia that at the onset became the basis or instrument of political struggle and now moves to the instrument of economic identity and practice. In the beginning of the reform period, sharia debate always wrestles with legal formal aspect in the legal institution frame, for example, in the form of regulation or decree. One milestone for the emergence 
of sharia discourse occurred in the beginning of the reform period, exactly in 1999-2002, when there was a wish to return to the Jakarta Charter with the demand on the implementation of Islamic law for Muslim adherents. ${ }^{1}$

A variety of civil and political movements campaigns actively for the importance of Islamic sharia application through state law, particularly local regulation. Utilizing an opportunity through decentralization and local autonomy, many areas have developed and implemented sharia local regulation (perda syariah). Referring to Lindsey, Otto records that there are 160 sharia local regulations distributed in 24 provinces in Indonesia. ${ }^{2}$

However, such condition seems to be no longer a trend since the last several years. Sharia nomenclature no longer becomes a hot topic in legal and political debates but leads to an economic activity label manifested into sharia hotel form or halal (rightful) label in food and beverage products thriving in many urban cities in the country. One of the areas indicating the prevalence of sharia-based hotel or accommodation service is Central Java, such as Solo Raya, Surakarta and the surrounding suburb areas. ${ }^{3}$ Therefore, in this study, I am concerned with sharia expansion in the economic field, not cultural aspects or other aspects.

Considering this shift or trend, it can be seen the significant change in the term of sharia from becoming regulation into economic label. This article should represent the change while suggesting the change of sharia use in daily life order. Through library study and non-participatory observation, this article attempts to show the most recent manifestation of sharia in economic fields. This is an important study to reveal that

${ }^{1}$ KhamamiZada, “W a cana Syariat Islam: Menangkap Potret Gerakan Islam di Indonesia," Tashwirul Afkar: Journal of Religion and Cultural 12 (2002): 27-28. See also, Nadirsyah Hosen, "Religion and the Indonesian Constitution: A Recent Debate," Journal of Southeast Asian Studies 36, no. 3 (October 2005): 425.

${ }^{2}$ Jan Michiel Otto, Sharia and National Law in Muslim Countries: Tensions and Opportunities for Dutch and EU Foreign Policy (Leiden: Leiden University Press, 2008), 461.

${ }^{3}$ M. Zainal Anwar, "Syariah dalam Industri Akomodasi di Solo: Antara Ekspresi Ketaatan dan Strategi Bisnis" (forthcoming in book chapter, n.d.). 
contemporary sharia is something alive and in accordance to context and interest of many parties.

This study argues that the widening of the meaning of sharia is inseparable from the interest of many parties utilizing sharia to show both political and business interests. The rising of such interest cannot be divorced from social, economic, and political conditions that underpin it.

This article starts with an introduction and is followed with various definitions of sharia. Thereafter, I address the emergence of sharia discourse as local regulation, economic brand, and sharia expansion from political identity to economic identity.

\section{Contemporary Sharia}

Normatively, sharia is often conceived or defined as "a road toward a water source". Conceptually, sharia is a divinely predefined road in which human should direct his/her life to implement Allah's wish including theology (aqida), moral (akhlaq) and worship. In other words, it is any stipulations and laws existing in the Quran and Sunna related to belief, ethics and human deed in the form of worship (ibada) and social interaction and contracts (muamala). ${ }^{4}$

Considering the phenomenon observed in this article, related to the shift of sharia's orientation and position, the normative meaning seems to be insufficient to use. I therefore pick up the four categories of sharia meaning suggested by Otto. ${ }^{5}$ Firstly, the divine aspect of sharia is Allah's rule or plan becoming guidance for all human beings. This first definition or category is almost acceptable to all Muslim groups, either moderate or puritan. This definition is also the one commonly used by most Muslims.

Secondly, the classical sharia is religion rule and principle organized by Muslim scholars in two first centuries since the death of Prophet Muhammad until the "closing gate of intellectual exercise (ijtihad)". The sharia in this second meaning can be seen in

${ }^{4}$ Fazlur Rahman, Islam, trans. Ahsin Muhammad (Bandung: Pustaka, 1984), 140-166. See also, Abdullah Ahmed al-Na'îm, Dekonstruksi Syari'ah: Wacana Kebebasan Sipil, Hak Asasi Manusia dan Hubungan Internasional dalam Islam, trans. Ahmad Suady and Amiruddin Ar-Rany (Yogyakarta: LKiS, 2001), 25.

${ }^{5}$ Otto, Sharia and National Law, 25-26. 
Muslim scholars' classical work of jurisprudence and the development of legal school (madhhab) as well as in other fields, such as politics, Sufism and economics. This second meaning is more historical in nature as it is utilized to investigate the dynamic of Islam as religion, political and sociological entities in the past.

Thirdly, the historical sharia is all principles and rules developed by Muslim religious scholars or intellectuals along the history since the era of the closing of the gate of scholar exercise (insid $\bar{a} d b \bar{a} b$ al-ijtihād) in the tenth century until today. Definition of sharia, its scope and implementation are eventually affected by space and time where it operates and by the people where they live in. Sharia formulation is contingent upon agencies, be they groups, institutions or states in Muslim society.

Fourthly, the contemporary sharia is the definition of sharia containing a broad spectrum developing and applying to many levels and aspects by many actors. In this phase, sharia is largely influenced by contemporary contexts or situation such as migration, modernization, and new technology invention in information and communication area. Another influence comes from colleges as well, embarking on studying sharia aspect in many areas ranging from banking to accommodation sector.

Considering the perspective above, sharia no longer has single definition but it has diverse definitions different from one time and area to another. ${ }^{6}$ Although, originally sharia leans more to worship aspect and is often associated with Islamic law (figh), it is not so in its most recent development. Sharia can legitimatize or even claim a struggle for political interest but can also be utilized to support economic interests and business activities.

It is based on those perspective of sharia developed by Otto that this study aims at understanding sharia discourse dynamic ever developing in daily life. Sharia has broad dimensions and no longer reflects a narrower meaning in the aspect of relationship between creatures and Allah but also in societal relationship. Moreover, sharia in the context of Indonesia has been an interesting and developing discourse, especially upon the post-

6 Michael Barry Hooker, Indonesian Syariah: Defining a National School of Islamic Law (Singa pore: ISEAS Publishing, 2008), 1. 
reform where it covers a wide range of discourse and practice. This article will present the expression of sharia in the beginning of reform period until today.

\section{Expression of Sharia in the Post New Order}

The discourse and practice of sharia in the post-new order regime shows its most dynamic and articulation due to the political impetus that encourage it. ${ }^{7}$ This is exactly different from the previous era where religion can also become part of the state development project provided that it was in line with the state control. The New Order regime was able to co-opt religion and especially Islamic expression and made use of it in his own purpose, particularly in the last period of his presidency before being toppled by the stream of reform. In the subsequent period, the discourse of Islam and sharia developed significantly in coincidence with the rise of Islam politics. This leads the sharia into one of the most important discourse in the national political spectrum. As a result, some sharia-inspired bylaws were enacted in some provinces and regencies across the country.

It is well-established that reform is the entrance for the return of discussion about sharia in Indonesia. This discussion about sharia can be observed at least in two moments: annual meetings of House of Representatives in 2001 in which two Islam-based parties in parliaments, United Development Party (Partai Persatuan Pembangunan/PPP) and Crescent Party (Partai Bulan Bintang/PBB), proposed the inclusion of the "seven words" about into the state law or constitution. They imagined that because Indonesia is a Muslim majority country and because the Jakarta Charter used to be apply, then there was no wrong to invoke it when there was need for it. ${ }^{8}$ However, many parties declined the proposal. The opponents considered the seven words would cause discrimination to non-Muslim population because Indonesia was not an Islamic state; it was a state based on Pancasila that upholds multi-religious and cultural society.

${ }^{7}$ Hooker mentions that the attempt of implementing sharia in Indonesia post-re form is not in vacuum condition but articula te $\mathrm{d}$ in modern sta te. Ibid., 281.

8 Zada, "Wacana Syariat Islam," 27-28. 
When the proposal was unsuccessful, the strategy of shariatization and the discourse of it shifted. It then took the issue of decentralization as an entry point to which sharia can be inserted. Local Autonomy Law No. 22/1999 became the starting point of decentralization and local democracy in Indonesia where the central government would not control almost every aspect of provincial and local government as it used to be. ${ }^{9}$ It was now time for the local government to be more active in determining their own fate

However, due to its centralistic nuance, the Local Autonomy law was then revised with Law No. 32/2004. Anwar suggests that the broad authority in managing region in decentralization and local autonomy era has encouraged any regions claiming to be majority Muslim and having structural power to develop sharia local regulation (perda syariah). ${ }^{10}$ Sharia bylaws is a form of local (provincial and regency) regulation developed by the local government agencies where part of norms, spirits and stipulations of Islamic law are infused into the legal system at the local level. ${ }^{11}$ This necessities various interpretation of what part from sharia should and will be taken into consideration since each province and regency or municipality encounters different issues and problems.

One of the regions that adopt sharia bylaws is Nanggroe Aceh Darussalam when it earned a special autonomy status in 2001.12

9 Abu Bakar Eby Hara, "Pancasila and The Perda Syariah Deba tes in The Post Suharto Era: Toward a New Political Consensus," in Islam in Contention: Rethinking Islam and State in Indonesia, ed. Ota Atsushi, Okamoto Masaki, and Ahmad Suaedy (Jakarta: Wahid Institute, CSEAS, and CAPAS, 2010), 43.

${ }^{10}$ M. Zainal Anwar, "Formalisasi Syari'at Islam di Indonesia: Pendekatan Pluralisme Politik dalam Kebijakan Publik," Millah: Jurnal Studi Agama 10, no. 2 (2011): 194.

${ }^{11}$ Ihsan Ali Fauzi and Saiful Mujani, eds., Gerakan Kebebasan Sipil: Studi dan Advokasi Kritis atas Perda Syariah (Jakarta: European Commission, Freedom Institute, and NALAR, 2009), 1.

12 Some reports about sharia implementation in Aceh can be found in Muhammad Ansor, "Being Woman in the Land of Shari'a: Politics of the Female Body, Piety, and Resistance in Langsa, Aceh," Al-Jami'ah: Journal of Islamic Studies 52, no. 1 (June 8, 2014): 59-83, and Reed Taylor, "Syariah as Heterotopia ; Responses from Muslim Women in Aceh, Indonesia," Religions 6, no. 2 (2015): 566-593. 
With this independency, Aceh enacted Islamic law code (qanun), the local terminology for sharia-nuanced local regulation. The culmination of the issuance of sharia local regulation, according to Tempo magazine's report, occurred in the period of 2003 through 2005. The magazine reported that there were about 90 sharia bylaws or sharia-inspired regulations both at the provincial and regency levels. In 2011, a special report by the magazine found that there were 150 sharia regulations at the local government. ${ }^{13}$ In the context of local autonomy, Sujito mentions that the representation of sharia development and implementation at the local level indicates the hardening of identity politics through the presence of sharia bylaws. ${ }^{14}$ The appeals of politics in the legislation of sharia bylaws became evidence as many Islamic organizations were formed to respond to it. For example, the establishment of the Committee of Sharia Law Preparation and Implementation (Komite Persiapan Penegakan Syariat Islam/KPPSI), in South Sulawesi. ${ }^{15}$

According to the Tempo magazine's report, ${ }^{16}$ there are several regions that pronounce sharia-based regulations: West Sumatera,

13 “Di Bawah Lindungan Syariah," Tempo Magazine, 2011, August 29 September 4 edition, sec. Special Coverage of Tempo Magazine.

14 Arie Sujito, "Konstruksi Politik Identitas Keagamaan (Catatan Gejala Munculnya Perda Syariah di Tiga Daerah di Indonesia)" (presented at the The 9th International Seminar on "Identity Politics: Religion, Ethnicity, and Space in Local Political Dynamics in Indone sia and South East Asia," PercikSalatiga, 2008) In his paper, Sujito investigated the phenomenon of sharia local regulation emergence in three research sites: South Kalimantan (Banjarmasin, Martapura Cities, and Hulu Sungai Utara/Amuntai Regency), South Sulawesi (Bulukumba) and West Nusa Tenggara (Mataram, East Lombok and Dompu).

15 Alamsyah and Yusnita Ike Christianti, "KPPSI: Perjuangan Politik Identitas Islam di Sulawesi Selatan" (presented at the The 9th International Seminar on "Identity Politics: Religion, Ethnicity, and Space in Local Political Dynamics in Indonesia and South East Asia," Percik Salatiga, 2008). See also, Wahyuddin Halim, "Gerakan Formalisasi Syariat Islam melalui Instrumen Negara; Refleksi Kritis atas KPPSI," in Quo Vadis Islamic Studies in Indonesia? (Current Trends and Future Challanges), by Kamaruddin Amin, et al. (Makassar: PPs UIN Alauddin Makassar, 2006). Another reference is Mujiburrahman, "Politik Syariah: Perjuangan KPPSI Di Sulawesi Selatan," in Conservative Turn: Islam Indonesia Dalam Ancaman Fundamentalisme, ed. Martin van Bruinessen (Bandung: Mizan, 2014).

16 "Di Bawah Lindungan Syariah." 
Nanggroe Aceh Darussalam, Riau, South Sumatera, Bengkulu, and Lampung in Sumatera; Banten, West Java, East Java, and Central Java in Java; and Gorontalo, South Kalimantan, South Sulawesi and West Nusa Tenggara in other islands. Those regions largely have majority Muslim populations and culturally always have local leaders with a strong Islamic background. In the same vein, Nashir mentions that the phenomenon of Islamic sharia law implementation in regions is termed as "subway Islamization". Those regions are South Sulawesi, Nanggroe Aceh Darussalam, West Java, and some other areas like Banten, Riau, West Nusa Tenggara, and East Java. ${ }^{17}$

Overall, the content or substance of sharia-based regulation can be divided into several categories. Firstly, it is related to maintenance of public order or solution to social problems, such as prostitution, gambling, and alcohol consumption. Secondly, it is related to the acquirement of religious skills such as reading the Quran and paying zakat (alms). Thirdly, it is related to the adoption of religious symbols such as wearing Muslim dress. ${ }^{18}$ According to the Tempo report, the trend of the shariatization prevailed from 1999 through $2009 .{ }^{19}$ The report did not include an analysis to the situation of sharia bylaws booming in the subsequent years. It is therefore interesting to analyze the condition after the 2009 Election and asked why there was a sharp decline in this trend.

According to Buehler, the rise of shari'a bylaws in a number of provinces and regions in Indonesia cannot be separated from the politician's interest in getting vote particularly in contestation of the 2004 and 2009 Election. These are two election moments occurring in the "glory time" of sharia local regulation. Interestingly, politicians struggling for sharia rule intensely come not only from Islam-based party, but also from secular parties

17 Haedar Nashir, Gerakan Islam Syariat: Reproduksi Salafiyah Ideologis di Indonesia (Jakarta: Pusat Studi Agama dan Peradaban (PSAP) Muhammadiyah (Muha mmadiyah Religion and Civiliza tion Study Center), 2007), 283-380.

18 Robin Bush, "Regional Sharia Regulation in Indonesia: Anomaly or Symptom," in Expressing Islam: Religious Life and Politics in Indonesia, ed. Greg Fealy and Sally White (Singapore: ISEAS Publishing, 2008), 176.

19 This data of sharia local regulation refers to Interior Ministry. 
such as Golkar and PDI-P. ${ }^{20}$ It was not surprising why non-Islamic parties but nationalist parties such as Golkar and PDI-P were interested in promoting sharia-based law, or at least put it as one important issue in their campaign. These parties wanted to gain many votes from Muslim constituents and considered that the sharia law was one attractive agenda to attract their votes.

The 2009 election seems to be the peak of politicization of the sharia since it turned down afterward. Referring to Robin Bush's argument, ${ }^{21}$ the position of Islam remains important in political movement in Indonesia with various agendas. Upon the 2009 election, the issue on the sharia implementation was less relevant and thus no longer attractive to as a medium to gain Muslims' votes. It was substituted with more populist programs such as welfare and education. It was the time where sharia law politics ended slowly.

Considering the current situation, it may be argued that what Bush has observed seems to be correct since we have not heard any issue on sharia bylaws implementation. However, this does not mean that the sharia disappeared altogether; what we now find is that shari'a remains intact but its issues switched into economic and industrial areas, such as halal brand for food, beverage and even travel and hotels.

My own observation confirms this shifting trend. In Solo city, for example, in the last five years, there have been increasing phenomena of shariatization in hotel and guest houses service such as Syariah Hotel Solo, Zaen Hotel Syariah, and Hotel Syariah Arini, just to mention some. It is followed with the issuance of regulation concerning sharia accommodation by the Ministry of Tourism and Creative Economic Number 2/2014 on Guidelines of Sharia-Compliant Hotel Business Organization. Another response came from the Council of Indonesian Ulama (Majelis Ulama Indonesia/MUI) that issued a decree No. 108/DSN-MUI/X/2016 about the Guidelines of Tourism Organization based on Sharia Principle.

20 Michael Buehler, "Partainya Sekuler, Aturannya Syariah," Tempo Magazine, 2011, August 29 - September 4 edition.

${ }^{21}$ Bush, "Regional Sharia Regulation in Indonesia," 191. 
The ministerial regulation and the MUI's fatwa are of course not issued without considering the actual need of guidance and legal reference. They emerged just because there were demands from the society and business market that called for a new performance in the service that comply with the sharia law. In this context, the presence and development of sharia-labeled hotel or accommodation can be said as one factor encouraging the enactment of the regulation and the issuance of the fatwa. It is inevitable that the regulation now becomes guideline for the hotels in standardizing sharia-based accommodation services.

My study found two points related to the changing sharia reorientation in contemporary Indonesia from law to economics and industry. ${ }^{22}$ Firstly, sharia no longer appears in the form of bylaws but it goes further to the different direction, namely economic and business. Secondly, the middle-class Muslims are no longer interested in a tight regulation driven by the state, but prefer the sharia implementation aspect as a choice.

Another example of the emergence of sharia in the industrial arena is concerned with the halal label on food and beverage products. I observed on some modern stores in Solo Raya area, Central Java, and found that recently there are several non-food and -beverage products starting to include the halal label, such as pan and tissue. It is important to certify the tissue material with halal certification as its colorant, solvent, and fragrant substances should not contain alcohol and other proscribed material surely. ${ }^{23}$ Meanwhile, the regulation about halal product guarantee (Article 67 Law No.33/2014) obliges the halal label posting on the product marketed in Indonesia after having been enacted for five-years, but several non-food and -beverage products apparently want to have their product halal certified immediately.

The finding so far reveals that the sharia discourse in contemporary Indonesia has been very dynamic. In the beginning of the reform period, sharia was very popular as a local political

22 Anwar, "Syariah dalam Industri Akomodasi di Solo."

${ }^{23}$ Muhamad Bari Baihaqi, "APP Komitmen Sediakan Tissue Sehat dan Halal," Harian Ekonomi Neraca, accessed September 10, 2017, http://www.neraca.co.id/article/71603/app-komitmen-sediakan-tissue-sehat-danhalal/. 
instrument, indicated with the prevalence of demand for sharia law implementation in the form of local regulations or decrees. However, in some recent years, sharia is used more as label or identity in economic-industrial world, as can be seen from the posting of sharia-label on industrial products, as this will be discussed in the following passage.

\section{Contemporary Sharia: A Shift from Politics to Economics}

Post-reform sharia shows off a unique face. In early years after the authoritarian regime collapsed, sharia became a battle field of political contestation, thereby becoming the base of political movement, particularly at the local level. This continued up to the subsequent ten years. Thereafter, sharia is no longer rousing as a struggle instrument in political frame. Consequently, sharia is used widely as label in economic activities, characterized with the use of sharia label in accommodation of business and industry demands.

In the last two elections (2009 and 2014), sharia issue is no longer piercing as the legal formal need. It changed considerably. Sharia situation around the local political moment was different in the period of 2005-2010 in which so many local politicians used sharia as a strategy of attracting constituents. Bush records many political events attempted to use sharia as political campaign, for example, the one occurring in Indramayu-West Java in 2005 and Mataram City- West Nusa Tenggara in 2005. ${ }^{24}$

In the framework of local politics, Ahok's case in the election of Governor of Jakarta in 2017 could bring up the symbols of political Islam in the campaign. So, can this be regarded as the momentum of the return of sharia in contemporary Indonesian politics? It seems to me that the Ahok case is a trigger to reuse the symbols of political Islam in the legal and political spheres formally. We need to re-examine local electoral events in various provinces and cities/districts by 2018 and the legislative and presidential elections in 2019.

${ }^{24}$ Bush, “Regional Sharia Regulation in Indonesia," 187-188. 
Referring to sharia conceptualization developed by Otto, ${ }^{25}$ the definition of sharia in Indonesia is not fixed but is dynamic. When it is used as the frame of state order political struggle in which there is a demand for sharia to be reference in local regulation development, sharia is defined as a guideline for all human's life ranging from moral aspect to religion tenet. All aspects of life, from dressing recommendation to religion tenet implementation, are governed in the frame of sharia-based regulation. In this context, sharia is defined as guideline and reference for societal governance.

However, this situation changes when sharia becomes an industrial label. Sharia is no longer voiced in political stage but it has shifted to being economic identity manifested in accommodation industry such as hotel or guest house. In Otto's term, this phenomenon is called "the contemporary sharia" or the sharia having moved expansively to economic area due to modernization influence and some of Muslim communities' lifestyle.

Regarding Muslim communities' lifestyle, I refer to what Yuswohady has called it the revival of millennial generation and their consciousness of all sharia-based lifestyle demands. ${ }^{26}$ Therefore, sharia-compliant hotels and other rightful (halal) industries emerge. In other words, the sharia discourse is not limited in political arena involving politicians and activists but it has become everyday life conversation generating the wish to consume everything with sharia label.

Consuming sharia-compliant industry not only shows religious fidelity but also reveals the identity of the person subscribes to it. When accessing sharia-based service, the consumers indirectly show that they have implemented sharia. It will likely be different from the compulsion to implement regulation-based sharia.

Viewed from revenue aspect, sharia seems to be different as well. In the period when sharia is enacted through local regulation

${ }^{25}$ Otto, Sharia and National Law, 25-26.

26 Gen M Yuswohady et al., Generation Muslim (Yogyakarta: Bentang Pustaka, 2017), 30. 
and regent/municipal's decree, implementing sharia becomes a formal aspect and referring to regulation developed by government. Civil force police (Satuan Polisi Pamong Praja/Satpol $P P)$ used sharia-based local regulation to arrest women found working until late night without her legal associate or guardian, just like what occurred in Tangerang some years ago.

However, issues like these have been rare recently. People implement sharia by accessing sharia-compliant service voluntarily and without compulsion. Similarly, an informant says $^{27}$ that consuming sharia-compliant services such as shariacompliant hotel becomes some middle-class Muslim communities' need and a distinctive trend. Many hotel guests coming from Muslim young families stay in sharia-compliant hotels.

\section{Sharia Expansion: A Conclusion}

Contemporary sharia discourse in Indonesia has shifted from politics to economics. In the period prior to the reform era, the discourses of sharia were mostly tied with legal and political aspects, adhering to state law in the form of local regulation, approved by executives and legislatives, and regent or mayor's decrees, and executive domains. But in the latest development, the sharia discourse and practice have expanded extensively. It can be seen more in daily Muslim individuals' interest to comply with sharia-based standard in both economic and industry.

In other words, the sharia aspiration in the form of regulation has been less dominant as this has been indicated by the fading of sharia implementation issue or sharia regulation plan in electoral political events. The campaign about political Islam in Indonesia, such as the necessity to vote for Muslim leaders, had emerged in Ahok's case in the governor's election in Jakarta in 2017 but was apparently only a momentary phenomenon. We need to examine whether political campaigns on sharia issues re-emerged in the electoral and wider world of electoral politics in 2018-2019 or just a brief case in Jakarta.

${ }^{27}$ Interview with Atina Damayanti, Sales Executive Hotel Arini Syariah on September 2017. 
Referring to the case, the sharia in the contemporary Indonesian politics stagnated. However, sharia appears in economic and industrial spaces, as shown with the prevalence of sharia-labeled industrial products, supported with the emergence of ministry's regulations and the Indonesian Ulama's fatwa on halal guidance and service.

\section{References}

Alamsyah, and Yusnita Ike Christianti. "KPPSI: Perjuangan Politik Identitas Islam di Sulawesi Selatan." Percik Salatiga, 2008.

Ansor, Muhammad. "Being Woman in the Land of Shari'a: Politics of the Female Body, Piety, and Resistance in Langsa, Aceh." Al-Jami'ah: Journal of Islamic Studies 52, no. 1 (June 8, 2014): 5983.

Anwar, M. Zainal. "Formalisasi Syari'at Islam di Indonesia: Pendekatan Pluralisme Politik dalam Kebijakan Publik." Millah: Jurnal Studi Agama 10, no. 2 (2011): 191-212.

- - - "Syariah dalam Industri Akomodasi di Solo: Antara Ekspresi Ketaatan dan Strategi Bisnis." forthcoming in book chapter, n.d.

Baihaqi, Muhamad Bari. "APP Komitmen Sediakan Tissue Sehat dan Halal." Harian Ekonomi Neraca. Accessed September 10, 2017. http://www.neraca.co.id/article/71603/app-komitmensediakan-tissue-sehat-dan-halal/.

Buehler, Michael. "Partainya Sekuler, Aturannya Syariah." Tempo Magazine, 2011, August 29 - September 4 edition.

Bush, Robin. "Regional Sharia Regulation in Indonesia: Anomaly or Symptom." In Expressing Islam: Religious Life and Politics in Indonesia, edited by Greg Fealy and Sally White. Singapore: ISEAS Publishing, 2008.

Eby Hara, Abu Bakar. "Pancasila and The Perda Syariah Debates in The Post Suharto Era: Toward a New Political Consensus." In Islam in Contention: Rethinking Islam and State in Indonesia, edited by Ota Atsushi, Okamoto Masaki, and Ahmad Suaedy. Jakarta: Wahid Institute, CSEAS, and CAPAS, 2010. 
Fauzi, Ihsan Ali, and Saiful Mujani, eds. Gerakan Kebebasan Sipil : Studi dan Advokasi Kritis a tas Perda Syariah. Jakarta: European Commission, Freedom Institute, and NALAR, 2009.

Halim, Wahyuddin. "Gerakan Formalisasi Syariat Islam melalui Instrumen Negara; Refleksi Kritis atas KPPSI." In Quo Vadis Islamic Studies in Indonesia? (Current Trends and Future Challanges), by Kamaruddin Amin, et al. Makassar: PPs UIN Alauddin Makassar, 2006.

Hooker, Michael Barry. Indonesian Syariah: Defining a National School of Islamic Law. Singapore: ISEAS Publishing, 2008.

Hosen, Nadirsyah. "Religion and the Indonesian Constitution: A Recent Debate." Journal of Southeast Asian Studies 36, no. 3 (October 2005): 419-440.

al-Na'īm, Abdullah Ahmed. Dekonstruksi Syari'ah: Wacana Kebebasan Sipil, Hak Asasi Manusia dan Hubungan Internasional dalam Islam. Translated by Ahmad Suady and Amiruddin ArRany. Yogyakarta: LKiS, 2001.

Mujiburrahman. "Politik Syariah: Perjuangan KPPSI Di Sulawesi Selatan." In Conservative Turn: Islam Indonesia Dalam Ancaman Fundamentalisme, edited by Martin van Bruinessen. Bandung: Mizan, 2014.

Nashir, Haedar. Gerakan Islam Syariat: Reproduksi Salafiyah Ideologis di Indonesia. Jakarta: Pusat Studi Agama dan Peradaban (PSAP) Muhammadiyah (Muhammadiyah Religion and Civilization Study Center), 2007.

Otto, Jan Michiel. Sharia and National Law in Muslim Countries: Tensions and Opportunies for Dutch and EU Foreign Policy. Leiden: Leiden University Press, 2008.

Rahman, Fazlur. Islam. Translated by Ahsin Muhammad. Bandung: Pustaka, 1984.

Sujito, Arie. "Konstruksi Politik Identitas Keagamaan (Catatan Gejala Munculnya Perda Syariah di Tiga Daerah di Indonesia)." Percik Salatiga, 2008.

Taylor, Reed. "Syariah as Heterotopia; Responses from Muslim

Women in Aceh, Indonesia." Religions 6, no. 2 (2015): 566-593. Yuswohady et al., Gen M. Generation Muslim. Yogyakarta: Bentang Pustaka, 2017. 
Zada, Khamami. "Wacana Syariat Islam: Menangkap Potret Gerakan Islam di Indonesia." Tashwirul Afkar: Journal of Religion and Cultural 12 (2002).

“Di Bawah Lindungan Syariah." Tempo Magazine, 2011, August 29

- September 4 edition, sec. Special Coverage of Tempo Magazine. 